\title{
UNEQUAL DISTRIBUTION OF HOUSEHOLD TASKS IN THE WORKING MOTHER- THEMED NOVELS
}

\author{
Maya Kurnia Dewi[1], Mochamad Rizqi Adhi Pratama[2]
}

\author{
[1]mayakurnia@unw.ac.id, [2]rizqi.adhi@unw.ac.id \\ UniversitasNgudiWaluyo \\ Kabupaten Semarang, Central Java, Indonesia
}

\begin{abstract}
In many countries, the rate of women's participation in labor keeps increasing from time to time because of their educational level and economic condition. This condition leads to some changes concerning the gender roles in a family. However, it does not change the division of household tasks between husband and wife. Women are still considered responsible for doing most of the household tasks. This topic is often presented as the central theme in some literary works, particularly novels. This research examines three different novels, Opening Belle, I Don't Know How She Does It, and The Balance Project, by analyzing the inequality in dividing household tasks faced by the working mothers in the novels. This research uses a qualitative method consisting of description, reduction, and selection stages. The analysis results show that the working mothers still do most household tasks, while their husbands do not help them much. Although they can pay someone to help them do the tasks, however, the help is not as good as expected. They still have to struggle in combining household tasks and work, which eventually makes them feel exhausted.
\end{abstract}

Keywords: household task, inequality, working mother, novels

\section{INTRODUCTION}

The increase in the number of female workers is one of the important markers of economic growth. Note that a sharp increase in the number of female workers occurred in the 20th century, where the number of women participating in the labor market in early industrialized countries is shown in graph 1.0. This graph illustrates the level of participation of economically active women by combining data from OECD (Organization for Economic Cooperation and Development) members. The graph shows a positive trend in all countries, although starting at different points in time and continuing at different levels; yet the substantial and sustained increase in female labor force participation in rich countries remains a striking feature of economic and social change in the twentieth century.

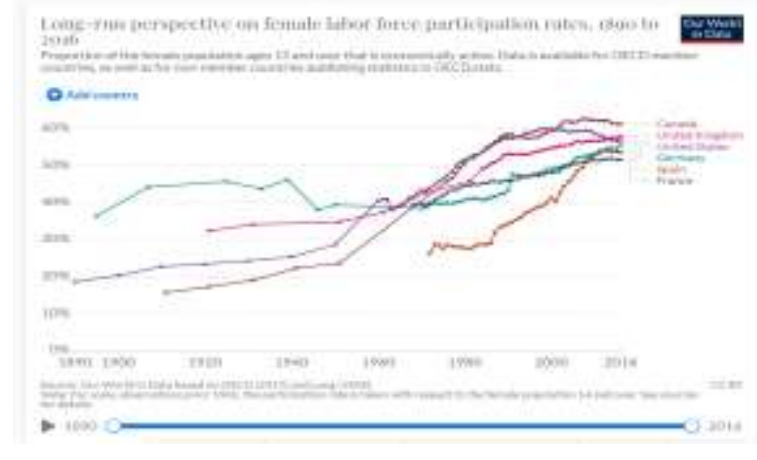

Figure 1. Long-Term Perspective of Female Labor Force Participation Rate from 1890 to 2016. (https://ourworldindata.org/female-labor-supply)

In many countries, women's participation in the world of work is increasing along with economic growth and increasing levels of education. Women need to have employment opportunities because work can help overcome gender gaps, such as income and decision-making in work. The increasing number of working women has 
changed some of the social treatment for women but has not entirely changed the role of women in the home. Women who work outside the home usually still have to play a role in caring for their home and family. Their husbands may contribute to taking out the trash or tidying the yard, but on average, they spend less time doing it than women do other household tasks. Indeed, full-time working women can pay someone to help at home. If a woman can pay for assistance, she will ultimately have to manage how this housemaid should clean the house or look after the children. She also still has to meet the needs of her children, including being involved in activities at school.

A survey conducted by the US Bureau of Labor Statistics in 2015 revealed that on average per day, women spend twice as much time preparing food and drinks as well as cleaning the house, and three times more time washing clothes than men. . Meanwhile, men spent twice as much time in activities related to the yard, garden, and repairs inside and outside the home than men. In principle, women spend more time on household tasks. The following graph shows it.

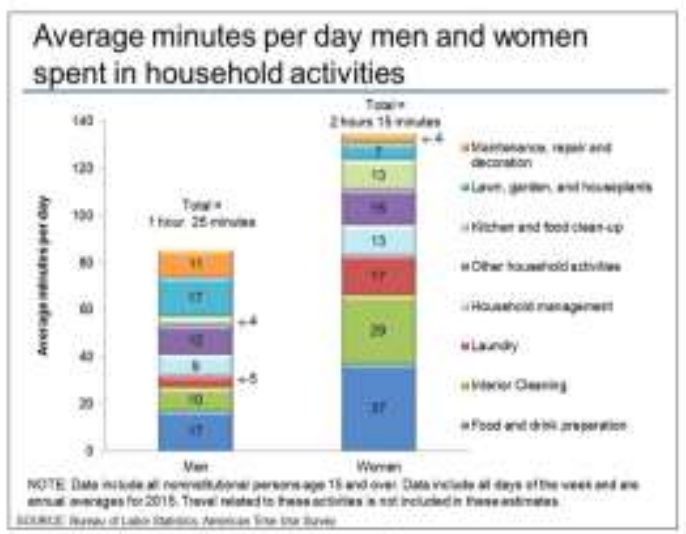

Figure 2. Comparison of the average time per day (in minutes) of men and women doing household tasks in the

(https://www.bls.gov/tus/charts/household.htm)

Household tasks consist of domestic duties, child care, and relatives. The gap in the division of household tasks between a working mother and her partner is due to the patriarchal understanding that defines household work as a woman's task. Working women have to play dual roles, namely at home and work, and they must balance these two roles well. The theme of inequality in the division of household tasks is raised in various literary works, primarily novels, so that this study will discuss the inequality conflict in the division of household tasks in four working mother-themed novels, namely Opening Belle, I Don't Know How She Does It, Kim Jiyoung, Born 1982 and The Balance Project.

Gender inequality in domestic tasks has been a valuable source of study in psychology as well as literature. Psychological studies involve a real-life investigation. Psychological effects are widely studied, especially those related to Work-Family Conflict (WFC) or work-family conflict today (Eby et al., 2005; Ammons and Kelly, 2015; French et al., 2017; Lapierre et al., 2017; Wayne et al., 2017; Carvalho et al., 2018).

Everyone, especially working women, has a high tendency to experience conflict between the office and domestic tasks due to limited time and high-stress levels (Greenhaus \& Beutel, 1985). Within psychological literature, there is a tradition of office and household tasks found in various works (Kopelmanś et al., 1983; Edwards and Rothbard, 2000; Pitt-Catsouphes et al., 2006; Mills, 2015; Paulin et al., 2017).

Cerrato (2018) investigated gender inequality in domestic work related to the increase in Work-Family Conflict (WFC). The results show that traditional gender roles still influence the way men and women manage work and family interactions.

Syamsuddin (2007) examines feminism in American society. The time setting is in the industrial era at the end of the 19th century. The primary source or data is the novel Main Street, written by Sinclair Lewis. The study revealed that at the end of the century, American women experienced discrimination and subordination. This novel promotes equality between men and women in social life.

Another leading researcher, Van Hooff (2011), investigated the explanations and justifications offered by multiple career heterosexual couples in maintaining an unequal division of domestic tasks in their relationship. Research findings reveal that some couples apply the same justification, with male and female respondents arguing that women have higher standards and are more competent in doing household tasks and that the definition of labor is practical, based on the hours they both work. 
Based on several studies above, there is still inequality in household work between men and women. This phenomenon triggers researchers to investigate this notion by focusing on several literary works in the form of novels. Novels can represent various things, including the author's view of real life.

\section{Method}

This study uses a qualitative research method which consists of the stages of description, reduction, and selection. The research phase begins by observing the depiction of the characters and problems raised in the novel, continued by reducing the information obtained from the description stage and focusing on the problems raised in the theme, then ending by connecting the data obtained with the theory used.

\section{Discussion}

Women's participation in the labor market has changed a lot in the last 50 years caused by many factors such as the absence of additional salaries, the husband's single income is no longer able to meet needs, the growing desire of women to enter public life and to gain economic independence, to the availability of childcare services (Dex, 2003, p. 10). The involvement of women in the economy has led to a change in traditional gender roles. Stereotypes of women who should play a significant role in household tasks now have to share their roles with tasks at work to be prone to conflict. Therefore he needs help from people around him so that he can carry out both roles well. Seccombe and Warner (2004, p. 431) divide household tasks into three interrelated activities: domestic tasks, child care, and family duties. This study will discuss the inequality conflict in the division of the household by discussing three novels with the theme of working mothers, namely I Don't Know How She Does It by Allison Pearson, Opening Belle by Maureen Sherry, Kim Jiyoung, Born 1928 by Cho NamJoo and The Balance Project by Susie Orman Schnalldan.

As mentioned above, several factors cause women to participate in earning a living. Sometimes they are forced to become the primary breadwinner in their household. In her novel Opening Belle Maureen Sherry was citing articles New York Times that wrote that... 40 percent of American households with children now have women being the primary breadwinner... (2016, p. 101). This condition is experienced by the main character in this novel named Isabelle McElroy. It is not much different from Katherine's character in the novel I Don't Know How She Does It. The husbands of these two figures have no fulltime jobs, so they have to provide for their families. However, increasing their participation in work does not change the traditional gender roles that have been held by a patriarchy so far.

The notion of patriarchy refers to the men's dominance over women and defines a system in which women are always subordinated in various ways (Bhasin, 2006, p. 3). Millet (1977, p. 35) adds that male domination is carried out through various institutions such as high schools, churches, and families, each of which justifies and strengthens the position of men over women. Kim Jiyoung, Born 1982 mentions many forms of patriarchal understanding adopted by the Korean people and passed down to subsequent generations.

When Kim Ji Yeong's mother was still a teenager, she must help pay for her younger brother's schooling because boys were expected to be successful in the family...boys are the core of family success and happiness (Cho, 2016, p. 33). In Kim Ji-Yeong's family, her grandmother treats her younger brother with special care, such as not giving him the task of helping his mother with household tasks and getting the best food at home. The birth of Kim Ji-Yeong and her older sister is also not considered a fortune in the family because they are expecting a son. So when JiYeong's mother was pregnant with her third child, when the doctor said that her child was thought to be a girl, Ji-Yeong's mother decided to abort her because her family impliedly would not accept if it were a girl. This situation makes sex testing and abortion of female fetuses widespread. The unequal gender ratio occurred between the 1980s and early 1990s when the number of boys was doubled compared to girls as the third child in the family.

Kim Ji-Yeong felt depressed when she was in a family gathering where family members shared that they felt restless after giving birth to a daughter. They feel proud in 
front of their in-laws when they are pregnant with a boy and are allowed to eat expensive food to their heart's content when they are pregnant with a boy.

Domestic roles attached to women often place women working in a conflict because, on the one hand, they must be fully responsible for domestic tasks, while on the other hand, they have responsibilities outside their homes, namely work. The significant difference in the division of household work continues when the wife works outside the home. Winqvist's research $(2004$, p. 44) shows that women in Europe spend between 60 and 70 percent of their time doing household tasks, while men spend 35 to 45 percent. This condition is similar to what happened in America. Katherine's character in the novel The Balance Project, who works as a writer, was interviewed by a journalist who asked why the balance between work and household tasks is still a hot issue. Kate says, "Well, women make up approximately 60 percent of the American workforce, yet they spend twice as many hours as men on childcare and housework" (Schnall, 2015, pp. 6-7).

Domestication is part of the feminine mystique described by the feminist character Betty Friedan in her book Feminine Mystique. In this book, he defines what is currently referred to as the stereotypical ideal woman as those who find feminine fulfillment when she focuses only on her husband, children, and home (Friedan, 1963, p. 18). The novel I Don't Know How She Does It shows domestication through religion when Kate opens a book entitled Saying of the World's Great Religion, which says that the wife is 'home' to emphasize the understanding of domestication of women. It causes Kate to feel guilty because she doesn't often stay home to take care of the house and her family. Patriarchal understanding causes Kate's husband not to feel what Kate feels when he has to work outside the home because this understanding says that the role of men is in the public sphere ...no man has ever had to ask for advice on how to combine fatherhood and a career (Pearson, 2002, p. 228).

The privilege of this male role causes them not to have to be involved in many activities related to household tasks so that if they are involved in it, they feel proud and can show it off to those around them. The two novels Opening Belle and I Don't Know How She Does It show readers how fathers display photos of their children on their desks to show that they can still make time for themselves amid their busy lives. Belle's character says, "Men have no problem. impressing their bosses with their family-man rap; while women never dare mention their families at work,"(Sherry, 2016, p. 85). In line with this, Kate's character says that if a man puts a photo of his child on the table, it shows that he is a good head of the family, while if a woman does this, the impression will be the opposite. It is because the nature of men is not at home with their children; It is women who have this responsibility.

\section{Inequality Conflicts in the Household-Task Division in the Novel I Don't Know How She Does It}

The novel I Don't Know How She Does It tells the story of Katherine or often called Kate, a successful career woman who works at a leading financial company, Edwin Morgan Forster, as the youngest senior director. He is 35 years old and has two children, Emily and Ben. Her husband, Richard, works for a housing agency whose job is uncertain. In line with the title of this novel, Kate's daily life is full of considerations of who needs her attention the most, whether children, work, or husband. Even though Richard stays at home most of the time because he does not always get a job, Kate still has to do various household tasks. The task of cooking, for example, was still Kate's responsibility even though at that time she came home from work late at night. This task he had to do because he read a letter from Emily's school asking Emily to bring snacks in celebration of the school's Christmas party. Kate concludes that every letter from school addressed to parents is addressed to the mother...(Has a father who has a wife on the premises ever read a note from school?) (Pearson, 2002, p. 4). Kate is willing to do this because she remembers that when she was a child, her friend who brought food from the store at the Harvest Festival at the church was considered to have a mother who ignored her child because she was busy working. He does not want Emily to get the same treatment that can make Emily feel sad and psychologically affect Emily until she grows up. 
Besides cooking, Kate's household tasks are cleaning the house, which she does after she finishes cooking snacks for Emily. He saw that the kitchen was in disarray; toys scattered all over the place, piles of raisins that had been there since morning, rotten fruit still on the dinner table, and dirty napkins that no one else thought of throwing away. Richard, her husband, asked her to rest because it was late, but Kate could not do it. Richard did not help Kate much with cleaning the house. Kate repeatedly reminded Richard to clean the house, but Richard often ignored Kate's requests:

11.19 P.M. Arrive home to discover the Pocket Memory Connect Kit on the hall table. Richard is shipwrecked on the sofa watching the Arsenal Game. He has left some pasta in the oven; it has the texture and smell of baked toes.

"Would it be totally out of question for anyone except me to take stuff left at the bottom of the stairs upstairs?" (Pearson, 2002, p. 142)

The task of cleaning the house seems to be a woman's destiny to do it as depicted in the character of Kate's mother, whose mother, as far as Kate can remember, was never sitting. He always stood at the sink, behind the ironing board, taking the plates of food from the kitchen and then picking it all up again. Her mother's generation was born to provide service, so she would lose her way if taken from her. When Kate was a teenager, she thought that although men seem to play an essential role in the real world, women enable men to appear in public well...It was a matriarchy pretending to be a patriarchy to keep the lads happy (Pearson, 2002, p. 281). This understanding is also shared by Kate's father-in-law, Barbara. In Barbara's life, husbands are not involved in household tasks at all. Barbara treated her husband like a farm animal that needed special care, so she would blame Kate if Richard looked thin. To ease the responsibilities of doing domestic tasks, Kate hires Juanita to clean her house. However, the help he expected from Juanita was difficult to fulfill because Juanita often complained of pain in various parts of her body, so that she was unable to clean the house thoroughly. As a result, Kate still has to do domestic tasks after work or on holidays. Shopping is also part of
Kate's job because Richard is often embarrassed when he is asked to buy household supplies identical to women. He told Kate that he refused to buy toilet paper, sanitary napkins, or air fresheners.

In addition to household tasks, inequalities in the distribution of household tasks are also evident in terms of child care. To help her take care of her children while she works, Kate hires a nanny named Paula, who is often late. Kate can go to work when Paula arrives, while Richard can leave without thinking about it. Paula's late arrival also causes Kate to be late for work. To avoid being poorly judged by his superiors, he has to give reasons for being late (called male reasons), such as traffic jams on the road. If he gives reasons for his delay because he has to take care of his children first, he will be considered an employee who does not put the company's interests first.

Nevertheless, on the other hand, society still demands a mother as the party most responsible for ensuring the welfare of her child. Paula is someone Kate can rely on when she is not at home. Problems will arise when Paula cannot come to Kate's house because she is sick. This situation causes Kate to try to find a way out before she can leave for work while Richard is gone for a project presentation. Kate, scheduled to chair an important meeting that day, decided to leave Ben and Emily with her neighbors for a while. A mother is also required to be able to cope with her child who is sick. Ten-month-old Ben is in his teething stage, which makes him cry a lot at night. While exhausted from work, Kate wakes up immediately when she hears Ben's screams, while Richard is still fast asleep. To ease the pain, Ben accidentally bites Kate's neck until it is red, and his coworkers ask about the wound.

"Hey, did Slow Richard give you a hickey? That's terrific honey."

"No, the teething baby did. My darling husband slept through all. But I nearly bit him to wake him up (Pearson, 2002, p. 78)

Child welfare also involves parents' participation in the education of their children. Emily's friends' mothers expect Kate to attend the parent-teacher meeting before Kate gets home from work. As a result, three 
months after joining, Kate never attended a single meeting. From the very beginning, Kate's goal in joining this organization was to contribute to Emily's education like Emily's friends who become housewives. ...I was thinking that just for one hour in some underlit overheated classroom, I could pretend that I'm like any other mother (Pearson, 2002, p. 214). Alexandra Law, the head of this organization, often quips that Kate is still working full time so she cannot play much of a role in school activities. Another activity at Emily's school that Kate wants to attend is a Christmas play performance which she can barely attend because she has a sudden assignment from her boss. He finally arrived late, which was indicated by the sound of his shoes on Emily's school floor, which seemed to be made to expose the working mother who was late. Kate wanted to attend this show. After all, she could not make it last year because she had to catch a flight to America. The times he could not come were the ones the kids would remember, not the other way around.

The third type of household task is the task of relatives or often called kin work. Amid her busy life, Kate still has to think about the Christmas gifts she should bring to celebrate at her in-laws' house. The process of giving gifts starting from buying wrapping paper, buying gifts, giving greetings in them to sending them through the post office is entirely done by Kate. One tradition is that I buy all the presents for my side of the family [] and presents for Richard's parents ....(Pearson, 2002, pp. 42-43). But when they were at Richard's parents' house, Richard's mother and father would thank Richard for bringing them gifts and wine. Kate felt unappreciated for her efforts.

To make up for her guilt because she could not play much in her child's growth and development, Kate bought various things to please her children. Currently, Emily has a variety of toys that mark Kate's guilt. Kate's guilt surfaced even before Emily was born. Kate is the first woman to become pregnant on Edwin Morgan Forster's investment arm. When she was six months pregnant, she was called by her boss, who said she could not guarantee there would be work once Kate returned from maternity leave. This company has a friendly policy towards married employees, but because men have never used policies such as maternity leave, women should also not use them and serious about work. As a result, Kate tries to work harder so as not to lose her job. Entering the 32nd-week pregnancy, Kate was told by her obstetrician that Kate was too stressed that it could harm her baby's brain development. Kate's guilt has made her choose to give birth vaginally without the help of an epidural injection so she can prove to her baby that there is still something she wants to endure.

To balance the roles at home and work, a working mother must be able to do many things at one time or referred to as multitasking. Kate told her husband that she needed to remember everything, while it was impossible to ask Rich to remember three things at the same time. In addition, a working mother must also be seen to be able to separate the two roles. When she is at home, she has to act as a mother, but she has to act as a good employee when she is at the office.

This conflict of inequalities in the division of household tasks makes Kate exhausted. She feels guilty because she often leaves her children, who are in their infancy and need him very much. He finally chose to sacrifice his job to be with his family. In conflicts related to home and work, the wife usually has to give in to quitting work because the primary breadwinner is her husband. This kind of conflict is also faced by another working mother character named Jill CooperClark. Jill Cooper-Clark, is the wife of Kate's boss in the novel I Don't Know How She Does It. Jill had a promising career at the Ministry of Home Affairs until Sam, her second child, was two years old. His position should have been high by now, but he decided to take care of his family. According to her, it is impossible for her and her husband, Robin, to have both fulltime jobs without impacting the development of their children. When faced with something like this, the wife is usually forced to choose to stop working because she is the main party responsible for matters related to the family. It is different from men who socially and patriarchally do not choose between work and family because their leading position is in the public sphere, while women are in the domestic sphere.

Even the novel I Don't Know How She Does It presents several chapters dealing with 
courts for working mothers. This court is tasked with prosecuting the working mother, in this case, Kate, if she does not know things are happening at home. For example, when Kate told her mother-in-law that Emily liked broccoli when, in fact, she did not. The judge in this trial accused Kate of being guilty because this should be known to a mother, although a child's tastes are constantly changing. Kate feels this accusation is unfair because Richard did not know about this either, but he was not found guilty

....well, there's no way that Richard would know whether Emily liked broccoli or not, but him not knowing seems normal. The mother not knowing, it feels unnatural..."(Pearson, 2002, p. 59).

\section{Inequality Conflicts in the Household-Task Division in the Novel Opening Belle}

The second novel that will be discussed in this research is entitled Opening Belle by Maureen Sherry. The main character in this novel is a working mother named Isabelle McElroy in her 30s. She is married to Bruce Cassidy and has three children. Isabelle or Belle works as an executive manager at a stock company called Feagin Dixon located in the Wall Street complex. Belle's husband, Bruce, does not have a regular job and is at home more often than Belle. One of the domestic tasks that Belle does is shopping for daily necessities. Her husband, Bruce, does not care if the fridge is empty, so Belle must be responsible for buying daily necessities. Having three young children makes Isabelle and Bruce's house never look clean. Isabelle's full-time job means she does not have time to clean her house, so she hires a domestic helper. However, her housekeeper often came home when the house was still a mess, and Bruce did not bother to clean it up. They let this happen because they got used to it, and Belle would sort it out in the end. One day because Kate got angry about this and said:

"It says nobody cares at all. It says let all this shit hang out till Mom comes home because she'll fix everything. She'll earn the money! She'll order all the groceries and arrange for cleaning and cooking..." (Sherry, 2016, pp. 268-267).
Meanwhile, Belle still plays a more dominant role in terms of child care than her husband, even though her husband is with them more often. Belle's friend says, "I think you're still doing most of the kid work even though he's home most of the time." (Sherry, 2016, p. 214). Even though Belle often has to travel overseas for business matters, she still has to arrange all the necessities at home so that all activities can run well, such as whether Kevin, her eldest son, has been picked up after playing with his friends; what the housekeeper cooked for dinner and whether Owen, his youngest son, had a good nap. Belle is also responsible for choosing the clothes her children will wear tomorrow because when this responsibility was given to Bruce, he could not choose the appropriate clothes, like when Brigid's teacher told Belle that Brigid went to school without wearing underwear. Belle often covered up her family's condition by saying that Bruce played a significant role in taking care of the children so that her husband would not continue to be blamed for not working. "Bruce helps a lot with the kids." I lied (Sherry, 2016, p. 17). What Bruce often does is have fun with the money that Belle makes. Bruce was too lazy to find a job because he could rely on his wife's income. Bruce's immaturity is also seen when Belle has a meeting with other working mothers who have toddlers. Belle decided to join this playgroup meeting because she wanted to be more involved in her children's activities. Belle was almost late because she suddenly got an extra duty from her boss. When she got home, she found her nanny angry because he had to keep an eye on all the toddlers there while Bruce was busy drinking wine with Belle's guests.

Like Kate, Belle's responsibility is also the responsibility of her family; for example, she has to buy Christmas gifts for her family. Belle bought the gifts before she attended the office party before the Christmas holidays. Belle was embarrassed to bring this bag filled with toys to a party in her office because everyone looked elegant without a big bag filled with toys like her. This bag makes her look like a mother, so she wants to hide behind her friend, Marcus. Hide me, Marcus. I look like a mother, for God's sake...(Sherry, 2016, p. 5). The toy that Belle bought rang many times when Belle accidentally bumped 
into something. It attracted the attention of his friends, who were moved to play it, damaging one of the toys for his child.

Busyness makes Belle feel guilty for leaving her children too often. He felt like he had lost much time with them. Time passed made Belle realize that now her children are getting bigger. In reality, the time given to parents to raise their children is not as long as one might think because they grow up fast. Most things aren't there for us as long as we think that they will be (Sherry, 2016, p. 106). However, Belle has not been able to decide to stop working for now because her family still needs income from her. Even for Belle's friends, combining work life with a family of three is impossible.

Nevertheless, this conflict makes Belle exhausted. Her coworkers often doubt her ability to get the job done because she has too many things to handle. He felt able to handle everything even though he also felt that his responsibilities were too much. I'm fully capable of taking care of Bruce and our brood; it's just so much responsibility. It's so lonely. (Sherry, 2016, p. 112). Belle also has to find a way so that she can always separate household and work matters. Belle called this separation by the term mental filing cabinet. Each piece is placed in a different container and ensures that no leakage occurs. It is often difficult to do, but not impossible.

"She jams a family problem into a mental filing cabinet, slams the door shut, and does her work. When she gets home she reverses the process, disconnecting her wireless world while reviewing first-grade spelling words.."(Sherry, 2016, p. 65)

Bruce's immaturity finally made Belle feel unable to maintain her household. She decided to divorce Bruce then stopped working from his previous company to set up his own business. By having her own business, Belle hopes that she will manage her working hours better to have time with her children.

\section{Inequality Conflicts in the Household-Task Division in the Novel Kim Jiyoung, Born 1982}

Novel Kim Jiyoung, Born 1982, picked up several working female figures, including Kim Ji Young's mother and Kim Jo Young herself. Ji
Young's mother is a housewife who works part-time to help with household finances. Ji Young's mother's jobs include gluing clothes, folding boxes, gluing envelopes, peeling garlic, rolling up window insulation, and others. She does not go to the office every day like her husband, who is a Civil Servant, but she does this job in addition to having to complete all household tasks..... while doing tasks all on her own and looking after three children and an elderly mother-in-law (Cho, 2016, p. 15). The most challenging job is rolling the window seals among all these side jobs because the glue used will stick tightly and often hurt if pulled too hard. Gradually the work of Kim Ji Young's mother grew, and the time she spent working longer and longer. One day Kim Ji Young's father came home after working late and still saw his children helping his mother roll up the insulation. He rebuked his wife for still letting his son work until late at night. Feeling guilty after this incident, Kim Ji Young's mother decided to stop all her side jobs.

Not only Kim Ji Young's mother is required to be responsible for household tasks. Ji Young's paternal grandmother, Go Sun-bun, even has to take care of all her family needs because her husband never wanted to take care of his family. However, Go Sun-bun fully accepted her husband's situation. She thought that her husband was a good man because he had not cheated on her and did not commit domestic violence against her.

As for the character Kim Ji Young herself, the notion of patriarchy has been instilled since she was a child because she and her older sister were assigned to help her mother wash the dishes or clean the house, while her younger brother was not given any task. This task continued until he had children. She has about three hours to do household tasks to wash clothes and dirty dishes piled up, clean the house and cook for her baby while she leaves her child in daycare. Many people think that housewives who leave their children can rest in peace. In reality, she still has to do housework during his free time.

In terms of child care, girls are also the most responsible party. JiYoung's mother said that Ji Young's sister used to cry a lot when she was little, so she took her to the hospital many times. Even when Ji Young and her sister were born, her father never helped take 
care of her child...I had three; your father never changed a single diaper... (Cho, 2016, p. 84). Another working woman character in this novel is doctor Ji Young, who also experiences inequality in parenting. At first, she and her husband thought that their child's mental condition was fine even though the two of them could not always accompany him because they had to work. One day his son's teacher told him that their son injured his friend's hand and did terrible things at school. Her child's teacher suggested better supervision of his mother for a while to improve his behavior. He ended up taking a temporary leave, but when his son's condition did not improve, he was forced to stop working.

In terms of establishing relationships with relatives, Kim Ji Young must be present at her in-laws' house to celebrate Chuseok with her husband's family. There she would help her mother-in-law buy groceries at the market and then cook before the rest of the family came.

Before getting married, Ji Young worked in a relatively large company with about fifty employees. Ji Young enjoys her work here because although the company she works for has many shortcomings and the salary she receives is not satisfactory, it has become a place where she is free to be herself. Initially, Ji Young was still working when she was declared pregnant, and her company allowed a pregnant female employee to come thirty minutes late to ensure her safety. However, when Ji-Yeong announces her pregnancy to her office colleagues, the male workers are jealous of this rule. Kim Ji Young is annoyed because they only see things in Ji-Yeong's favor without seeing the discomfort a pregnant woman experiences.

Ji Young wanted to keep working when she gave birth, but when she realized there was no one to turn to take care of her child, she was forced to stop working...In the end, they concluded that one of them had to be a stay-at-home parent, and that person, of course, was Ji-young (Cho, 2016, p. 79). The decision was finally made this way, considering that at that time, the husband's job was more stable and following the general assumption that the husband should work while the wife raised the children and took care of the house.
When her husband said that he would help Ji Young finish the housework after working, Ji Young was annoyed because she felt that her husband felt that he was the only one who would help if his wife felt tired while both wife and husband are responsible for household tasks. She also feels that a working mother decides to quit because she has to look after her child will lose many things, including youth, health, work, colleagues, friends, life plans, and future. At the same time, a husband will not lose many things when he has children. When a mother wants to return to work after giving birth, she will find it challenging to find a decent job. The available jobs include freelancers, private tutors, cashiers, restaurant waiters, or other parttime jobs because they still have to take care of their children.

\section{Inequality Conflicts in the Household-Task Division in the Novel The Balance Project}

The novel The Balance Project tells more about Lucy Cooper, an assistant to the famous writer Katherine Whitney, who wrote a book "The Balance Project," which tells how working women can balance roles at home and work. Katherine says that a woman can succeed in her career, household life, and life in her book. Because Kate can manage her work, her children are still small, and she can pay for housekeepers and nannies. Her husband, Theo, is also very supportive of her career. Although she does not spend much time with her children, Kate said they are always together as a family on weekends. He feels there are no problems in his household and his children seem happy. However, when her babysitter complains of getting sick almost every day while she has to take care of her business, she starts to feel overwhelmed and feels that now her life is a mess. "......I'm a mess. I don't know how I possibly thought I could manage all of this. It's too much." (Schnall, 2015 , p. 110). The impossibility of balancing career and household life is also expressed by another character in this novel named Dr. Elaine Ireland, who said:

.....This idea of being superwoman. That you can do everything-taking care of your career, your children, your marriage, and yourself-all really well and that everyone in that equation-your boss, your family, you- 
will be happy and sane and well all the time. But in reality, that's impossible ....."(Schnall, 2015, p. 175).

Contrary to her literary work, which reveals the possibility of balancing home and work life, in reality, Kate cannot do so. She finally decided to concentrate on his family and stopped working.

\section{CONCLUSION}

The working mother characters, both those who work full-time like Kate and those who work part-time like Kim Ji Young's mother, experience inequalities in the division of household tasks, including the distribution of household tasks (i.e., domestic tasks, child care, and duties towards relatives). This inequality in household tasks is due to the patriarchal understanding that places women in the domestic sphere and men in the public.

When a woman decides to enter the public sphere, their responsibilities in the domestic sphere have not changed much. They are still the primary party responsible for the domestic sphere. If they cannot fully handle household tasks, they should find someone who can help them. Both Kate characters finally decided to stop working because they found it challenging to handle both roles simultaneously. Meanwhile, the character Belle and Kim Ji Young's mother decided to open their own business to handle both realms more freely. The balance between work and domestic affairs for working mothers is still challenging to realize because of the patriarchal understanding that is still widely upheld by the community.

\section{REFERENCES}

Ammons, S. K., \& Kelly, E. L., eds (2015). Work and Family in the New Economy. Research in the Sociology of Work, Vol. 26. Bingley: Emerald Group Publishing Limited.

Bhasin, K. 2006. What is Patriarchy? New Delhi: Women Unlimited

Carvalho, V. S., Chambel, M. J., Neto, M., \& Lopes S. (2018). Does work-family conflict mediate the associations of job characteristics with employees' mental health among men and women? Front. Psychol. 9:966.

Cerrato, J., \&Cifre, E. (2018).Gender inequality in household tasks and work-family conflict.Frontiers in psychology, 9, 1330.

Cho, N. J. (2016). Kim Ji Young, Born 1982. New York: Liveright Publishing Corporation.

Dex, S. (2003). Families and Work in the Twentieth First Century. England: Joseph Rowntree Foundation.

Eby, L. T., Casper, W. J., Lockwood, A., Bordeaux, C., \& Brinley, A. (2005). Work and family research in IO/OB: Content analysis and review of the literature (1980-2002). Journal of vocational behavior, 66(1), 124-197.

Edwards, J. R., \& Rothbard, N. P. (2000). Mechanisms linking work and family: Clarifying the relationship between work and family constructs. Academy of management review, 25(1), 178-199.

French, K. A., Dumani, S., Allen, T. D., \& Shockley, K. M. (2017). A meta-analysis of work-family conflict and social support. Psychological bulletin, 144(3), 284.

Greenhaus, J. H., \& Beutell, N. J. (1985). Sources of conflict between work and family roles. Academy of management review, 10(1), 76-88. 
Kopelman, R. E., Greenhaus, J. H., \& Connolly, T. F. (1983). A model of work, family, and inter role conflict: A construct validation study. Organizational behavior and human performance, 32(2), 198-215.

Lapierre, L. M., Li, Y., Kwan, H. K., Greenhaus, J. H., DiRenzo, M. S., \& Shao, P. (2018). A meta-analysis of the antecedents of work-family enrichment. Journal of Organizational Behavior, 39(4), $385-401$.

Millet, K. (1977). Sexual Politics. London: Virago

Mills, M. J., ed. (2015). Gender and the Work-Family Experience: An Intersection of Two Domains. Springer, Cham.

Paulin, M., Lachance-Grzela, M., \& McGee, S. (2017). Bringing work home or bringing family to work: Personal and relational consequences for working parents. Journal of Family and Economic Issues, 38(4), 463-476.

Pearson, A. (2002). I Don't Know How She Does It. New York: Anchor Books

Pitt-Catsouphes, M., Kossek, E. E., \& Sweet, S. (Eds.). (2015). The work and family handbook: Multidisciplinary perspectives and approaches. Routledge.

Schnall, S. O.(2015). The Balance Project. Arizona: SparkPress

Seccombe, K. \&Warner, R. L. (2004). Marriages and Families. Relationships in Social Context. Australia: Thomson Wardsworth.

Sherry, M. (2016). Opening Belle.New York: The Glass Ceiling Group Inc.

Syamsuddin, S. (2007). Feminism in Sinclair Lewis'main Street. LiNGUA: Jurnal Ilmu Bahasa dan Sastra, 2(2).

Van Hooff, J. H. (2011). Rationalising inequality: heterosexual couples' explanations and justifications for the division of housework along traditionally gendered lines. Journal of gender studies, 20(01), 19-30.

Wayne, J. H., Butts, M. M., Casper, W. J., \& Allen, T. D. (2017). In search of balance: A conceptual and empirical integration of multiple meanings of work-family balance.Personnel Psychology, 70(1), 167-210.

Winqvist, K. (2004). How Europeans spend their time. Everyday life of women and men. Rapport de la Commission Européenne, Luxembourg: Pocketbooks Edition. 
LiNGUA Vol. 16, No. 1, June 2021 • ISSN 1693-4725• e-ISSN 2442-3823

98 | Unequal Distribution of Household Tasks in The Working Mother-Themed Novels 